NASA

Technical Memorandum 86939
USAAVSCOM

Technical Memorandum $84 \cdot C-2$

\title{
Experimental Study of Ceramic-Coated Tip Seals for Turbojet Engines
}

T.J. Biesiadny

Lewis Research Center

Cleveland, Ohio

G.A. Klann

Propulsion Laboratory

AVSCOM Research and Technology Laboratories

Lewis Research Center

Cleveland, Ohio

E.S. I dssow

Howmet Corporation

Whitehall, Michigan

M. McHenry

U.S. Army Aviation Logistics School

Fort Eustis, Virginia

G. McDonald and R.C. Hendricks

Lewis Research Center

Cleveland, Ohio

Prepared for the

Ninth Annual Conference on Composites and Advanced Ceramic Materials sponsored by the American Ceramic Society

Cocoa Beach, Florida, January 20-24, 1985

NMSA

(HASA-TA-E6939) EXPERIUBNIAI STUDY OF CERABIC CCATBD TIE SEALS FCE TUEBCJET

BHGINRS (MASA) $22 \mathrm{~F} \mathrm{HC} \triangle O 2 / E \mathrm{E} A 01$ CSCI 2OD

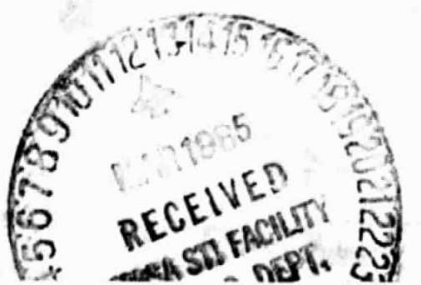

N85-19363

$$
63 / 34 \quad \begin{array}{ll}
\text { Unclas } \\
14267
\end{array}
$$


EXPERIMENTAL STUDY OF CERAMIC-COATED TIP SEALS FOR TURBOJET ENGINES

\author{
T.J. Blesiadny \\ National Aeronautics and Space Administration \\ Lewis Research Center \\ Cleveland, Oh10 44135 \\ G.A. Klann \\ Propulston Laboratory \\ AVSCOM Research and Technology Laboratories \\ Lew1s Research Center \\ Cleveland, Ohio 44135 \\ E.S. Lassow \\ Howmet Corporation \\ Whitehall, Michigan 49461 \\ M. McHenry \\ U.S. Army Aviation Logistics School \\ Fort Eustis, Virginia 23604 \\ G. McDonald and R.C. Hendricks \\ National Aeronautics and Space Administration \\ Lewis Research Center \\ Cleveland, Ohio 44135
}

\title{
SUMMARY
}

Ceramic gas-path seals were fabricated and successfully operated over 1000 cycles from flight idle to maximum power in a small turboshaft engine. The seals were fabricated by plasma spraying zirconia over a NiCoCrAlx borid coat on the Haynes 25 substrate. Coolant-side substrate temperatures and related engine parameters were recorded. Post-test inspection revealed "mudflat" surface crackirg with penetration to the ceramic - bond-coat interface.

\section{INTRODUCTION}

Replacing bill-of-material (BCM) metallic (nickel aluminide) turbine tip shrouds with ceramic shrouds can improve the efficlency of small turbojet engines. Higher gas path temperatures, less shroud cooling alr, or lower metal-substrate temperatures can be used, thereby extending component 11 fe or reducing component weight.

Testing of ceramic replacement materials has generaily been limited to rig testing of specimens, with some testing on large turbojet engines. Little has been done on small engines such as those in the $4.5-\mathrm{kg} / \mathrm{sec}(10-1 \mathrm{~b} / \mathrm{sec})$ airflow class to verify rig and analytical studies. Some of these studies can be summarized as follows:

(1) Short thermal cycles and the associated thermal stress were respons 1 ble for fallures of ceramic-coated rods subjected to a Mach 0.3 Jet A/air burner flame (ref. 1). 
(2) For sample sets of 20 ceramic-coated rod specimens and 22 ceramicinated disk specimens, the standard deviations werp large (half the norm), and both data sets were best represented by log-norma? distribution functions (ref. 2).

(3) Ceramic creep was established experimentally for a variety of configurations and heat treatments and shown to have a significant effect on thermal stress (ref. 3 ).

(4) The effects of thermomechanical loading of ceramic coatings were analyzed by three numerical methods: MARC, ADINA-ADINAT, and SINDA-FEATS (ref. 4). The methods produced stresses that were simflar and in all cases high enough to cause the coatings to fall.

(5) Inelastic behavior of the ceramic coating and the substrate was considered (ref. 5). Although the ceramic could creep, inelastic behavior of the substrate and ceramic produced high compressive stresses during and at the termination of the cooling cycle (ref. 6). These stresses can cause the ceramic coating to fall upon heatup or during subsequent cycles (refs. 1 and 6 ).

(6) Ceramic seal materials and seal configurations produced similar stress histories, with stresses large enough to cause the coatings to fall (ref. 7 ).

In the work presented herein, the BOM shroud configuration, a honeycomb structure of nickel aluminide, was replaced by plasma-sprayed $2 \mathrm{rO}_{2}-8 \mathrm{Pr}_{2} \mathrm{O}_{3}$ attached to the shroud base metal or substrate by a NiCoCrAlx 1 bond coat. The ceramic shrouds were constructed on the basis of lessons learned (refs. I to 7). All six BOM shroud segments were replaced with the ceramic-coated shroud specimens. The ceramic-coated specimens were then evaluated in an engine installation. Temperature profiles are presented for the BOM and ceramic shrouds, and the ceramic shrouds are shown before and after testing. An unabridged account of these experiments and the analytical work has been published (ref. 8).

\section{ENGINE INSTALLATION}

The first-stage, high-pressure turbine tip shrouds (fig. 1) were installed as six circumferential segments in a small $(4.5-\mathrm{kg} / \mathrm{sec}(10-1 \mathrm{~b} / \mathrm{sec})$ airflow class) front-drive turboshaft engine (ref. 9). The engine included an integral particle separator; a single-spool gas generator section consisting of a five-stage-axial and single-stage-centrifugal flow compressor; a throughflow annular combustor; a two-stage, axlal-flow gas generator (high pressure) turbine; and a free, two-stage, axial-flow power turbine. The engine was tested in a ground-level facility with Jet $A$ fuel. Because trace elements of certain metals such as vanadium pentoxide rapidly degrade the ceramic - bond-coat interface, the fuel was analyzed. The analysis revealed that the fuel was "clean."

The engine was limited to a power level less than maximum (approx. 96 percent of maximum $\mathrm{high}$ rotor speed) to prevent inadvertent trips to idle if the

\footnotetext{
$1_{N 1 C O C r A l-b a s e}$ composition, N1-23CO-19Cr-14AT-2.5Ta-1.4Mn-0.6Hf-0.3La.
} 
turbine temperature or rotor speed $11 \mathrm{mits}$ were reached. The temperature of the hot-side gas path was calculated from compressor discharge pressure and temperature, fuel flow, combustor efflctency, and cooling and leakage flow estimates. Even with the power restriction, gas-path temperatures over $1205^{\circ} \mathrm{C}$ $\left(2200^{\circ} \mathrm{F}\right)$ were reached during high-power operation.

A cross section through a typical turb!ne tip shroud segment is 1llustrated schematicaliy in figure 2, and the six shroud segments after application of the ceramic are shown in figure 3 .

\section{INSTRUMENTATION}

The shrouds were impingement cooled on the back side with compressor discharge air (fig. 2). Thermocouples were attached to the back side of each segment, two to a segment ( $\mathrm{fig} .4$; see also $\mathrm{fig} .13)$. The number of thermocouples was limited by the number of leads that couid be fed through the structure containing the impingement cooling holes without significantly altering the cooling pattern and by the number of ports (2) in the combustor outer wall housing.

\section{SEAL FABRICATION}

The substrate surface, Haynes 25 , also part of the BOM configuration, was prepared by cleaning and grit blasting with $\mathrm{Al}_{2} \mathrm{O}_{3}$. The NiCOCrAlX bond coat was then plasma sprayed onto the substrate in a low-pressure environment to a nominal thickness of $1.0 \mathrm{~mm}(0.040 \mathrm{in})($ ref. 10$)$. The component was then plasma sprayed, in air, with $1.0 \mathrm{~mm}(0.040 \mathrm{in})$ of high-porosity $\mathrm{ZrO}_{2}-8 \mathrm{Y}_{2} \mathrm{O}_{3}$ (YSZ) and subsequently diffusion heat treated to promote bonding and to alleviate NiCoCrAl strain (ref. 11). Excess materials were later ground to the engine contour for effective rub-free sealing.

\section{PROCEDURE \\ Transient Cycle Generation}

The engine operating cycle was $80 \mathrm{sec}$ at high power followed by $80 \mathrm{sec}$ at flight idle power with $1-\mathrm{sec}$ ramps between the two power levels (fig. 5). The substrate temperature reached equilibrlum during the heatup cycle (filght idle to high power) but did not quite attain equilibrium during the cooldown cycle (high power to flight idle). Plots of engine speed indicate an overshoot in speed for both the heatuo and cooldown cycles (fig. 6). These excursions were considered in calculating the gas-path temperature buc were not detected in the substrate temperature histories (fig. 7 ).

\section{Reasons for Cycle Chotce}

Creep, fallure criteria application, and thermal load affected the choice of operating cycle. The creep experienced by thermal barrier coatings is controlled primarily by the cumulative time at temperature under load and the rate of temperature change required to attain that temperature level. 
Therefore the shrouds must be cycled at a time interval long enough to reach and maintain that temperature before the cooldown cycle begins (ref. 5).

In an earlier work (ref. 2), 22 test samples were cycled in a Mach 0.3 burner. The data were compared with several fallure distributions (including Weibull, normal, and log-normal). The test group was most accurately modeled by the log-normal distribution. This distribution implies a decreasing hazard function with increasing time, which is opposite that of a Weibull distribution, where the hazard function increases with time. Therefore for the seals to be useful for potentiai engine applications a relatively large number of cycles had to be tested; 1001 cycles was chosen as a reasonable compromise.

To ensure safe engine operation with the ceramic shrouds, the 12 shroud thermocouples were monitored in real time by using an electronic bar graph display. The engine was partially disassembled for visual inspection of the ceramic seals ifter 4,210 , and 739 cycles.

\section{RESULTS AND DISCUSSION}

\section{Engine Test Results}

The engine was operated through 1001 cycles from idle power to high power and back to idle with the ceramic shrouds installed. The time from shroud installation to removal was $57.8 \mathrm{hr}$. This included initial shakedown tests of the engine facility and dally checks of the engine instrumentation. Typical aiceleration in engine high retor speed from idle to high power is shown in figure $6(a)$, and the corresponding calculated gas-path temperature and average of 12 thermocouples for the shroud back-side temperature are shown in figure $7(a)$. Similar data for deceleration are shown in figures $6(b)$ and $7($ b), respectively.

Normalized, steady-state shroud back-side temperatures after the first and the last (1001) cycles are shown in figure 8 . Thermocouples on shroud 6 were somewhat out of agreement with the trend established by the other thermocouples. However, the thermocouples showed no visua or electrical signs of distress under post-test inspection. Possit le explanitions include cooling hole blockage limitinr flow to this shroud; excess coo ant bleeds to the hot gas path; a thinner than normal ceramic coating; a variation in combustor temperature profile; and a variation in shroud-to-blade clearance from nominal. This problem has not been resolved.

The shrouds before installation and after removal are shown in figures 3 and 9 , respectively. The condition of the shrouds after removal is described in the analysis of the shroud seal material.

The back-side temperatures for the ceramic shroud after the first cycle were on the whole significantly lower than those for the BOM shroud (fig. 10). However, there were anomalles where the opposite was true, such as for thermocouples $1,10,11$, and 12 . This corroborates the previously observed higherthan-nominal temperatures near shroud 6 . Excluding these thermocouples, the average temperature difference between the ceramic and BOM shrouds was approxImately $78 \mathrm{deg} C(140 \mathrm{deg} F)$. 
A detalled metallurgical evaluation of a ceramic shroud segment is given in the appendix. Highlights of that evaluation follow here.

Examination of several sections through the ceramic shroud components (e.g., fig. 11) revealed nonuniform ceramic coating thicknesses as a result of spraying and grinding. 2

A macrograph of a shroud section (fig. 12(a)) shows surface cracking. On an average the "mudflat" cracks were hexagonally spaced br about $1.5 \mathrm{~mm}$. Such large cracks probably were preceded by microfracturing. These cracks tended to penetrate to the bond-coat interface (fig. 12(b)), where cracking appeared either to terminate or, in some instances, to spread axially and perhaps circumferentially. These cracks are probably responsible for the shroud's ability to withstand thermal cycling when an elastic analysis produces stresses beyond the rupture $11 \mathrm{mit}$. Such inelastlc behavior also limits the life of the component: as microfracturing effects become prominent, the structure weakens and eventually falls.

\section{CONCLUDING REMARKS}

Ceramic turbine tip shrouds were experimentally evaluated in the operating environment of a small turboshaft engine under steady and transient conditions.

1. Gas-path seals were fabricated by plasma spraying $1.0 \mathrm{~mm}(0.040 \mathrm{in})$ of $2 \mathrm{rO}_{2}-8 \mathrm{Y}_{2} \mathrm{O}_{3}$ (YSZ) and $1.0 \mathrm{~mm}(0.040 \mathrm{in})$ of a $\mathrm{N} 1 \mathrm{COCrAi}$-base bond coat onto a bill-of-material Haynes 25 substrate

2. The seals were installed in the engine shroud support assembly and ground to meet engine clearance specifications. The effect of grinding on surface microfracturing is unclear.

3. The $2 \mathrm{rO}_{2}-8 \mathrm{Y}_{2} \mathrm{O}_{3}$ (YSZ) ceramic shrouds were subjected to 1001 cycles between engine idle and high power as well as to steady-state conditions for a total of $57.8 \mathrm{hr}$.

4. Microfracturing, which produced "mudflat" cracking as a result of tensile stresses in the ceramic, appeared to provide a mechanism for strain reduction but also provided the fallure mechanism during an extended life.

5. Micrographs of the surface and cross-section morphology 1llustrate the surface cracks and those penetrating to the ceramic - bond-coat interface.

6. The average circumferential temperature profiles on the back sides of the shrouds were lower for the ceramic shrouds than for the BOM shrouds by approximately $78 \mathrm{deg} C(140 \mathrm{deg} F)$, but some anomalies remain to be explained.

2 The wet grind left a residue on the coolant passage that provided flow visualization of jet impingement patterns (e.g., see fig. 13). 
It is recommended that future experimental research work in this area continue with emphasis on thicker ceramic layers, different ceramic application techniques, less dense ceramics, and a better definition of the radial temperature and strain profiles through the ceramic shrouds by using more thermocouples and implanting strain gauges. 


\section{APPENDIX}

\section{CERAMIC SHROIID METALLURGICAL EVALUATION}

\section{Macroscopic Observations}

One $2 \mathrm{rO}_{2}-8 \mathrm{Y}_{2} \mathrm{O}_{3}$ ceramic shroud section (position 6) along with a typical cross section, has been metallographically examined (by Gary Liotta of General Electric, Lynn, Mass.). The front surface of shroud 6 was reasonably smooth without visible defects (fig. 9). Some slight erosion was evident, along with a small amount of ceramic darkening. At a magnification of 32 ( $\mathrm{fig} .14)$, the back surface showed cracking in the bond coat along the tralling edge and extending back into the ceramic flowpath surface. Some ceramic cracking was also evident along the leading edge, along with some "micro" surface cracks. The right end of the shroud showed both yertical and bond-line cracking. Of the total perimeter length of $24.4 \mathrm{~cm}(9.6 \mathrm{ln}), 9 \mathrm{~cm}(3.6 \mathrm{in})$, or approximately 37.5 percent, was cracked.

\section{Metallographic Observations}

For the sectloned shroud (fig. 11), the bond coat was 1.14 to $1.27 \mathrm{~mm}$ $(0.045$ to $0.050 \mathrm{in})$ thick. Adjacent to the leading and tralling eiges the bond coat was about 50 percent dense $(\mathrm{f} / \mathrm{g} .15)$. Vertical cracking was also evident in the bond coat.

The ceramic top coat was 0.76 to $0.98 \mathrm{~mm}(0.030$ to $0.039 \mathrm{in})$ thick. Probably this was closer to $1.27 \mathrm{~mm}(0.050 \mathrm{in})$ before grinding. The bond coat had cracked at the tralling edge (fig. 15(b)); the crack extended almost $1.9 \mathrm{~mm}$ $(0.075 \mathrm{in})$ from the tralling edge to the leading edge and $12.7 \mathrm{~mm}(0.500 \mathrm{in})$ from right to left.

\section{Additional Metallurgical Studies}

A second independent study of the shroud seal morphology was conducted by Ellot Lassow of Howmet Turbine Components Corp. Micrographs showing typical pretest and post-tesit microstructures of the plasma-sprayed coatings $\left(\mathrm{ZrO}_{2}-\right.$ $8 \mathrm{Y}_{2} \mathrm{O}_{3}$; NiCOCrAlX) as applied to the engine shrou's segments were examined. Sectioning locations are given in figure 16.

A pretest micrograph (fig. $17(a)$ ) of a quality control specimen that was not run in the engine revealed some ver'cical cracking, which provides strain re?lef. The post-test ceramic coating microstructure (figs. 17(b) and (c)) revealed extensive segmentation, commonly called mudflat cracking, and some local areas of lateral cracking and large porosity. Apparently some densification of the ceramic occurred. However, caution inust be exercised as microstructures are very dependent on metallographlc polishing methods.

The metallic bond coat exhibited considerable porosity predominantly as a result of pullout during metallographic polishing, which was optimized to reveal the ceramic microstructure. Extensive porosity adjacent to the leading and tralling edges was due to the geometry of the part not having been optimized for plasma spray coating. There was no evidence of any significant oxidation or beta-phase (NIAI) depletion of the NiCoCrAlX bond coat. The 
thickness of the metall:: and ceramic layers in sections A-A ano B-B varied because the process was not fully optimized.

\section{REFERENCES}

1. G.E. McDonald and R.C. Hendricks, "Effect of Cycling on Vttria Stabilized Z1rconla Plasma Sprayed Coatinys," NASA TM-81480, 1980.

2. R.C. Hendricks and G. McDonald, "The Rssessment of the Variations in Thermai Cycle Life Data of Thermal-Barrier-Coated Rods," Thin Solid Films, 84. 105 (1981).

3. R.C. Hendricks, G. McDonald, and R.L. Mullen, "The Effect of Annealing on the Creep of Plasma-Sprayed Ceramics," Ceram. Eng. Sc1. Proc., 4 [9-10] $819-827$ (1983).

4. R.C. Hendricks, G. McDonald, R.L. Mullen, M.J. Braun, and B.T. Chung, "Thermomechanical Loading of Multilayered Cylindrical Geometries in Thermal Cycling from 300 to $1300 \mathrm{~K}$," Presented at the ASME/JSME Thermal Engineering Joint Conference, Honolulu, Hawa11, Mar. 1983.

5. J. Padovan, G. McDonald, R.C. Hendricks, R.L. Mullen, B.T.F. Chung, and M.J. Braun, "plastic Flow of Plasma Sprayed Ceramics," pp. 473-485 in Proceedings of An International Symposium on Plastic Deformation of Ceramic Materials, Plenum, New York, 1983.

6. J. Padovan, D. Dougherty: R.C. Hendricks; M.J. Braun, and B.T.F. Chung, "High Temperature Thermomechanical Analys!s of Ceramic Coatings," Journal of Thermal Stresses, I, 51-74 (1983).

7. J. Padeyen, D. Dougherty, R.C. Hendricks, G. McDonald, M.J. Braun, and B.F.T. Chung, "Thermomechanical Analysis of Ceramic Gas-Path Seals," Ceram. Eng. Sc1. Proc., 5 [7-8] (1984).

8. T.J. Blestadny, E.E. McDonald, R.C. Hendricks, J.K. Little, R.A. Robinson, G.A. Klann, and E. Lassow, "Experimental and Analytical Study of Ceramic-Coated Turbine-Tip Shroud Seals for Small Turbojet Engines," TM-86881, 1985.

9. General Electric Corp., Alrcraft Engine Group, Report SEI-418, June 1978.

10. S. Shankar, D.E. Koen1g, and L.E. Dard1, "Vacuum Plasma Sprayed Metallic Coatings," J. Met.. 33. [10] 12-20 (1981). 


\section{OPMGHTAL PAGS IS
OF POOR QUALITY}

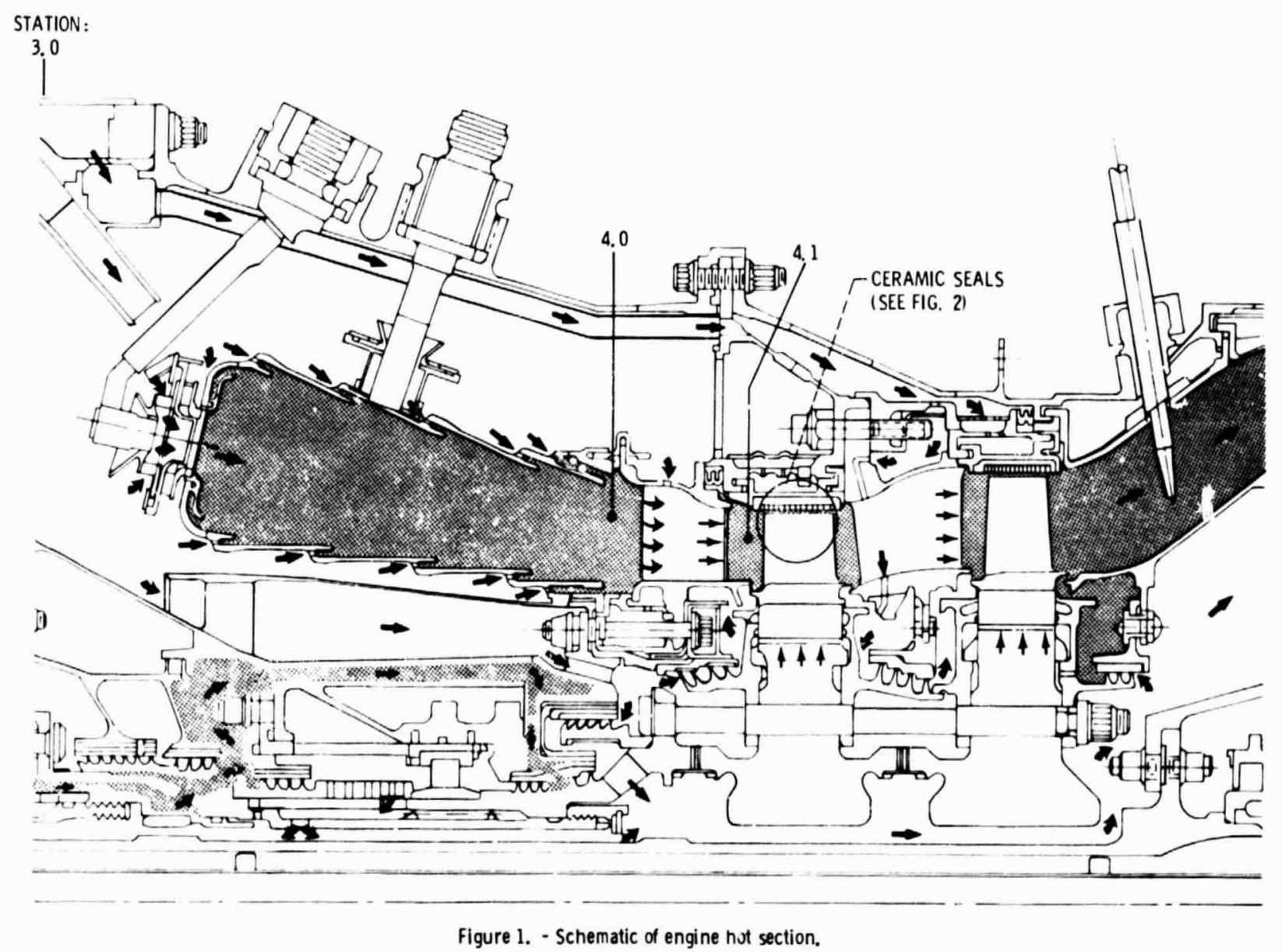

Figure 1. - Schematic of engine hot section, 


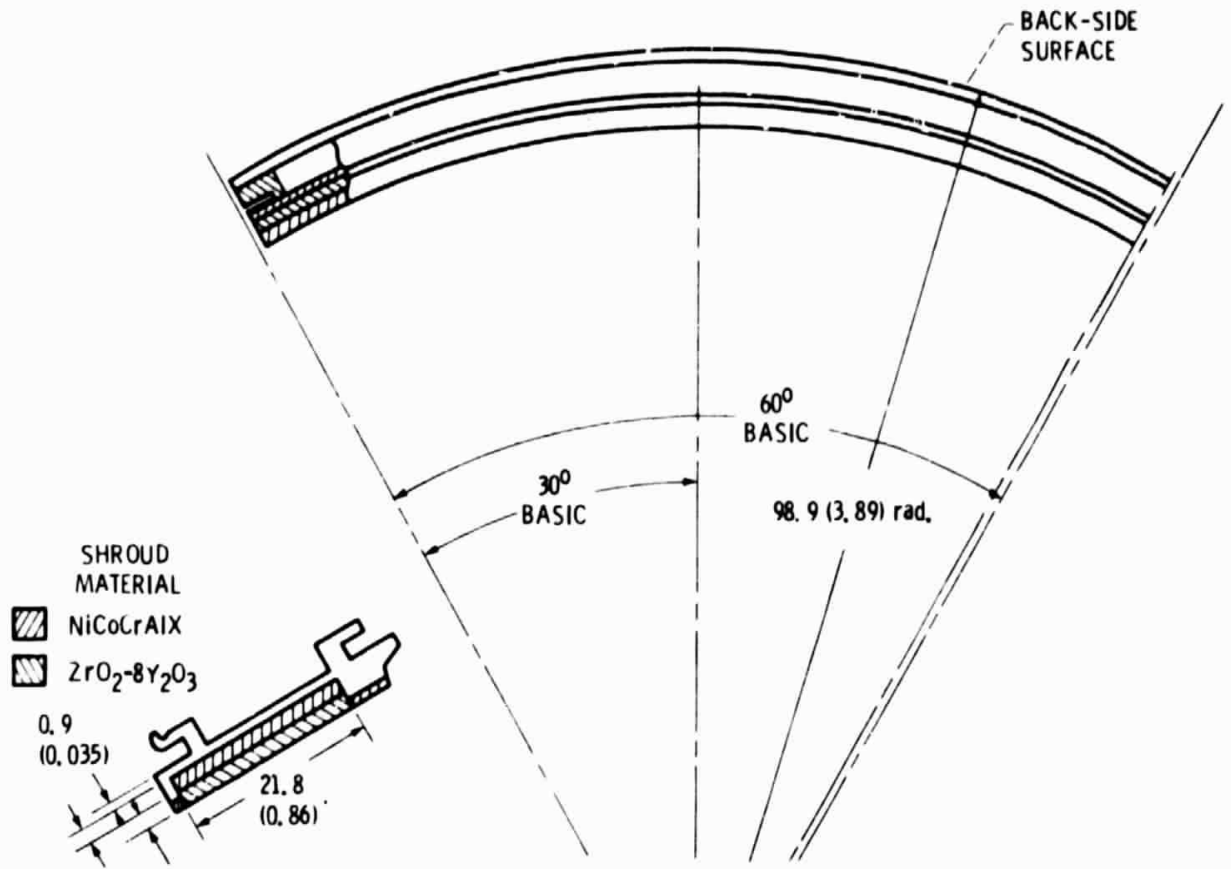

$1.0(0.040) 1.0(0.040)$

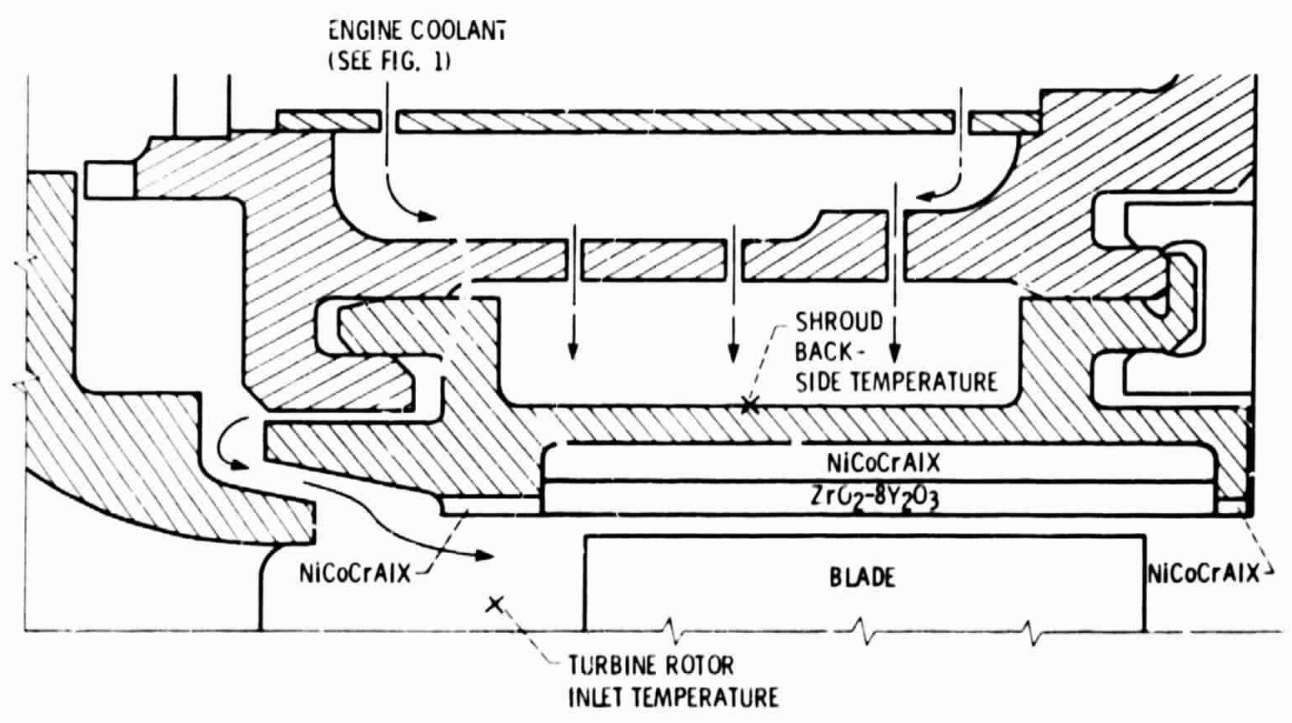

Figure 2. - Schematic of ceramic-coated shroud seal. (Dimensions are in millimeters (inch).) 
(4)

ORIGINAL PAGE
OF POOR QUALITY

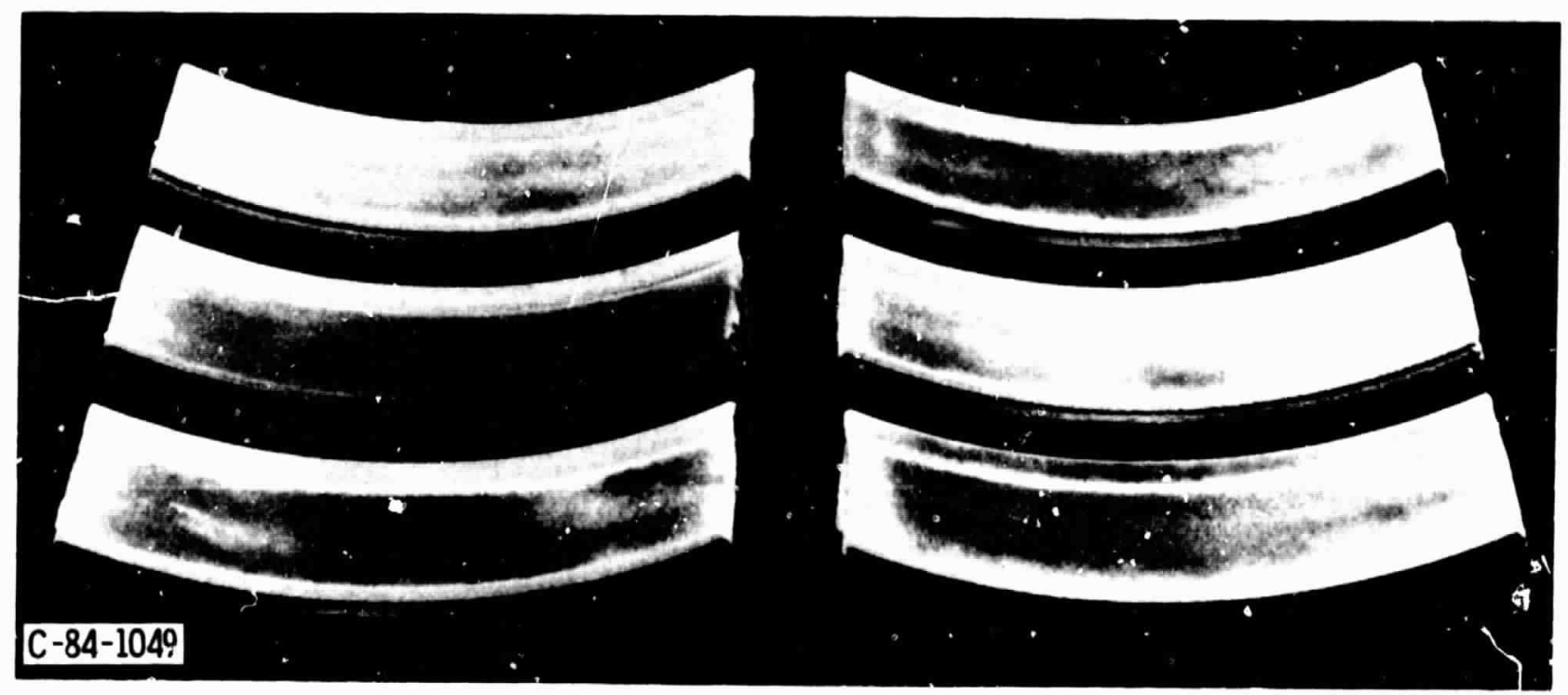

Figure 3. - Shroud segments after plasma spraying. 


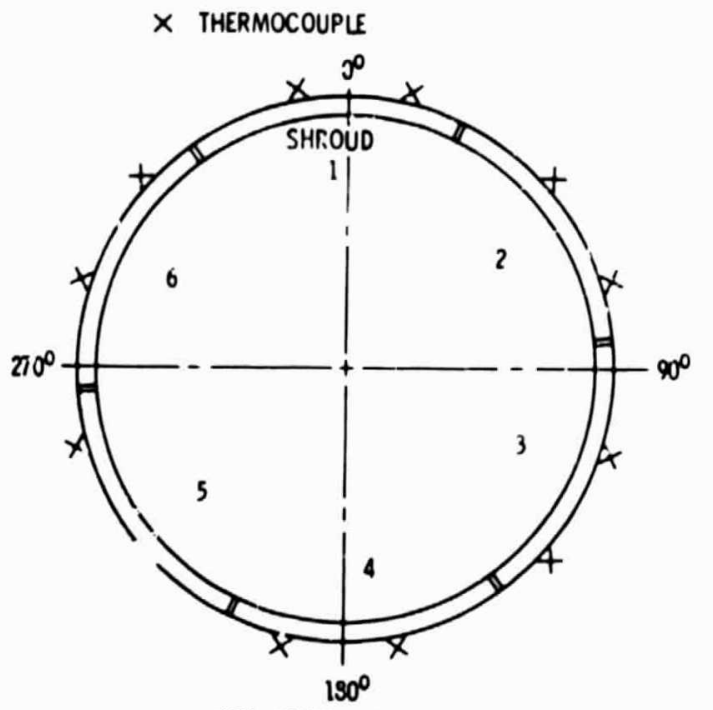

AFT, LOOKING FORWARD

Figure 4 - Position of thermocouples on turbine tip shrouds.

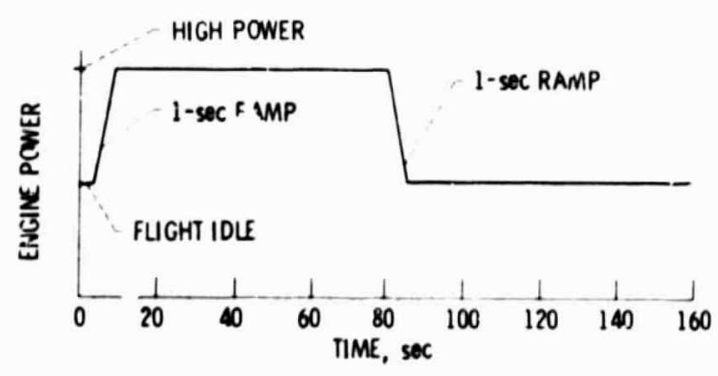

Figure 5. - Typical transient test cycle. 


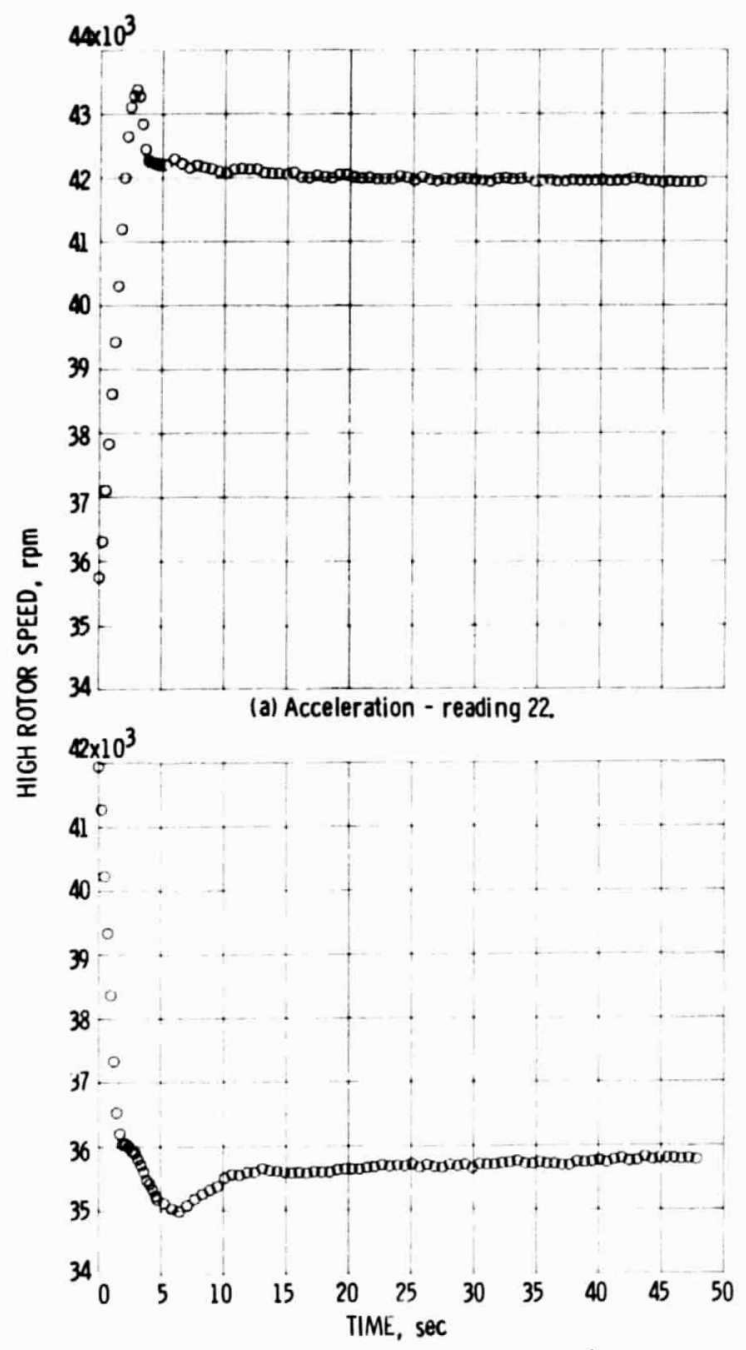

(b) Deceleration - reading 23.

Figure 6. - Variation of high rotor speed with time. 


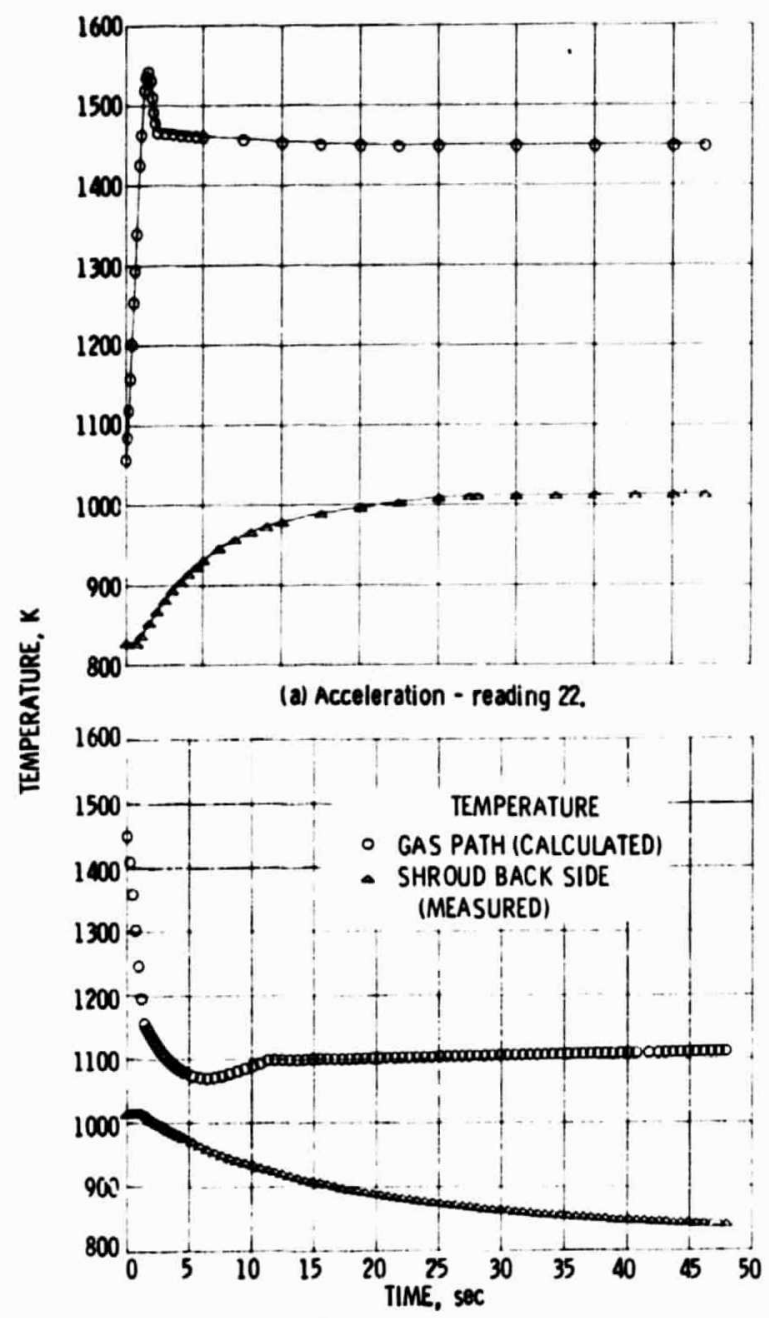

(b) Deceleration - reading 23.

Figure 7. - Variation of average shroud back-side temperature and gas-path temperature with time. 


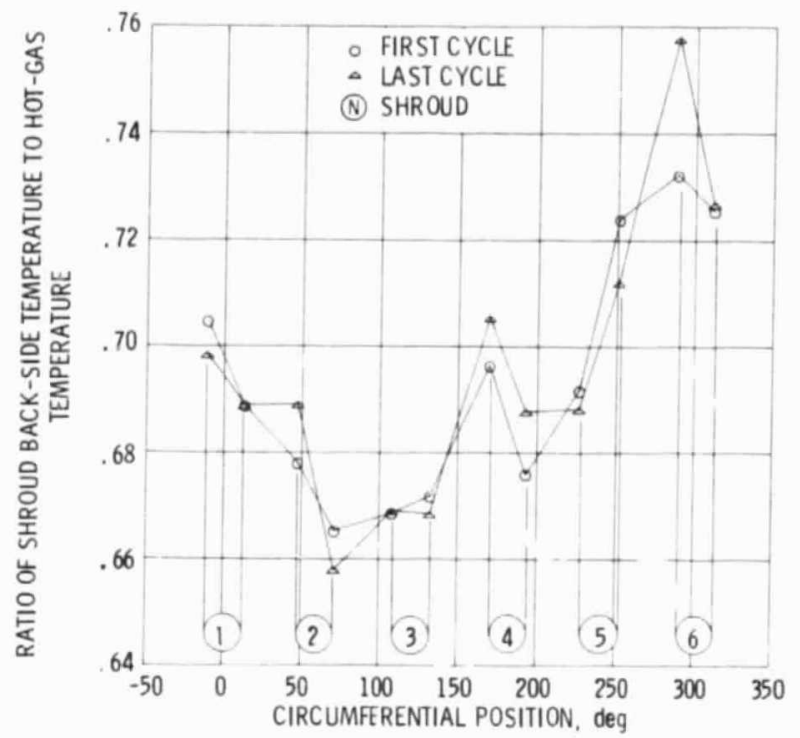

Figure 8. - Normalized shroud back-side temperatures at high power for first and last (1001) cycles.

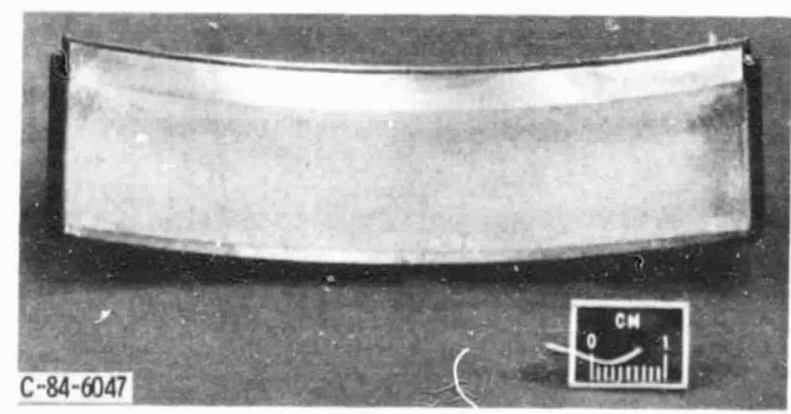

Figure 9. - Shroud segment 6 after 1001 cycles - hot-gas side. 


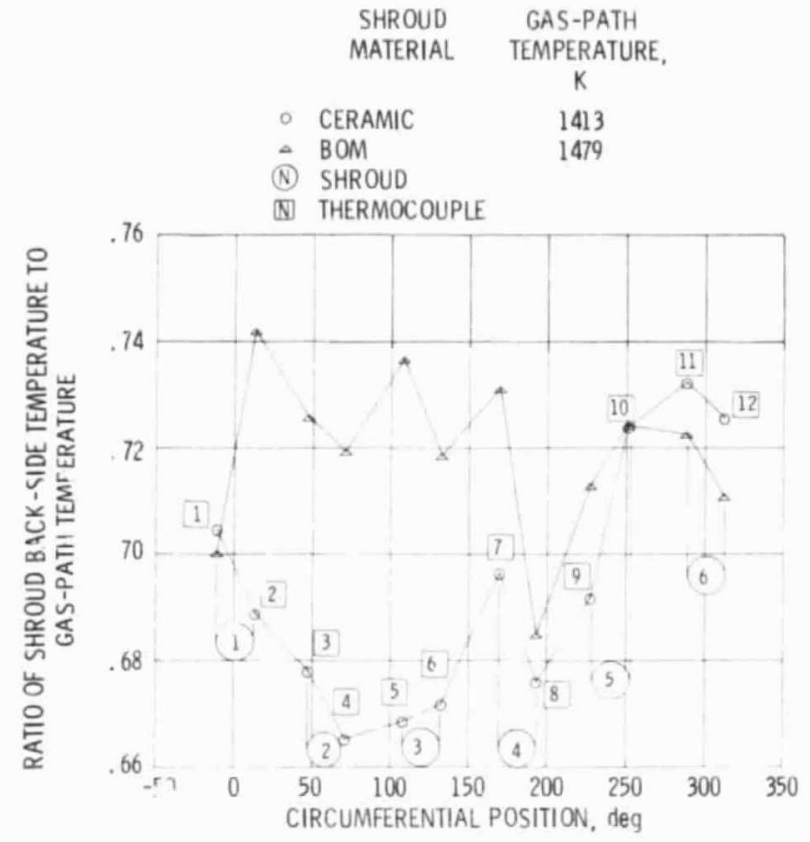

Figure 10. - Ceramic and BOM shroud back-side temperatures at high power after 1 cycle.

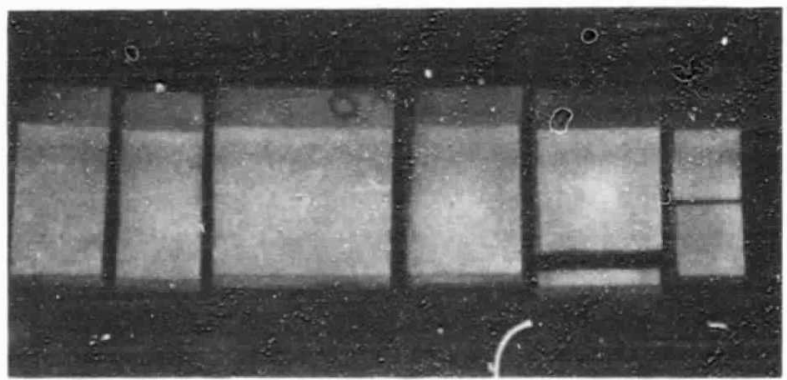

Figure 11. - Shroud sections used in metallographic analysis. 
ORIGINAL PRGË IS

OF POOR QUALITY

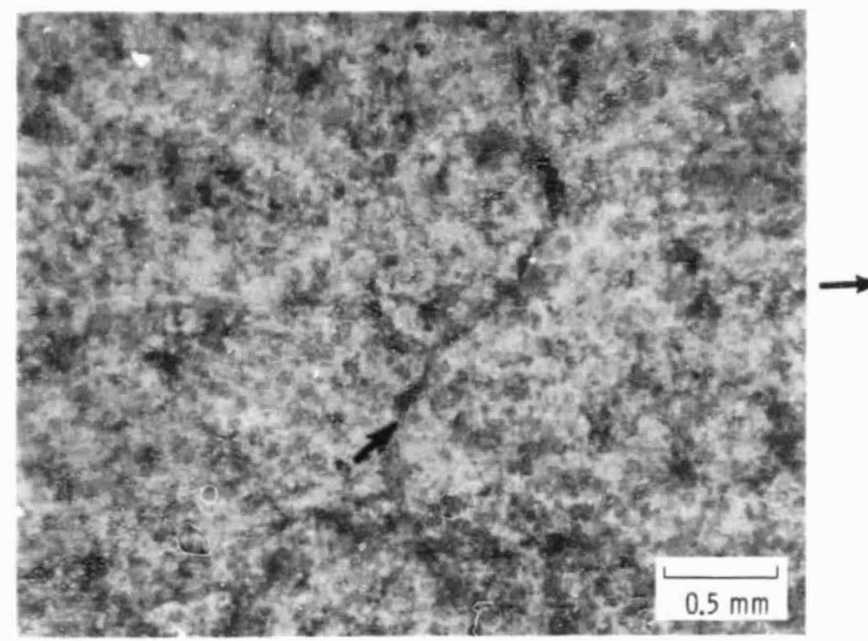

(a) Typical flow path crack.

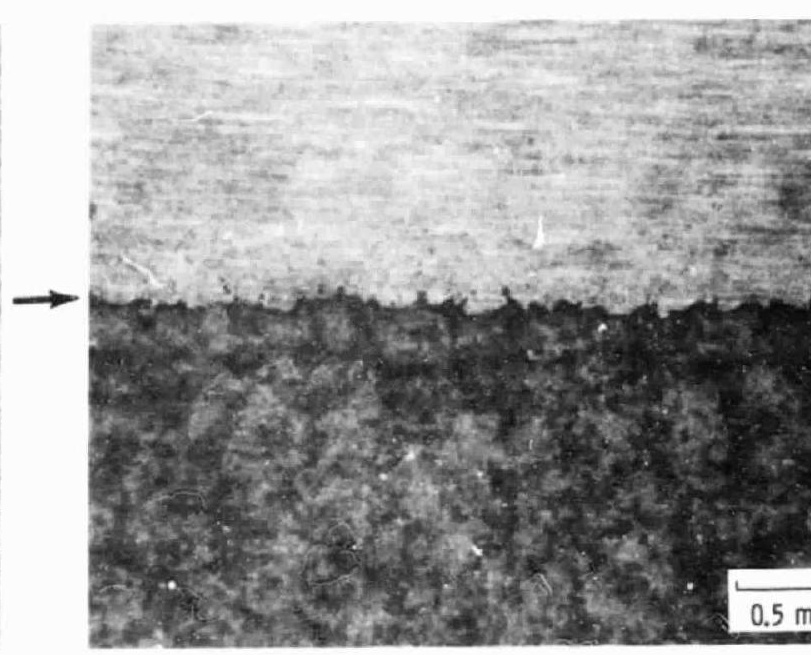

(b) Ceramic crack leading edge.

Figure 12. - Macrographs of ceramic shroud section.

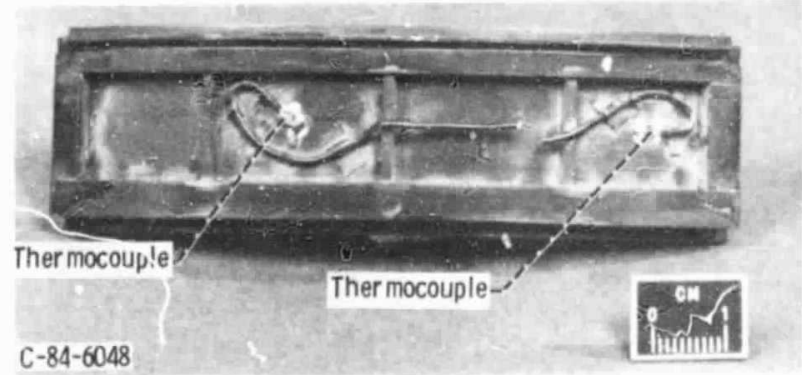

Figure 13. - Shroud seqrient 6 after 1001 cycles - back side. 


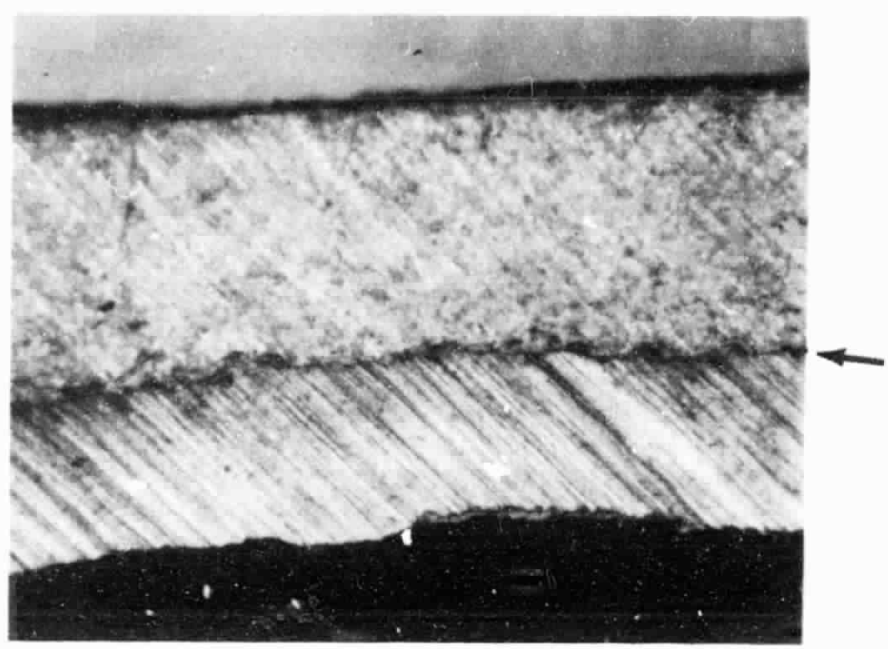

(a) Ceramic and frame crack trailing edge.

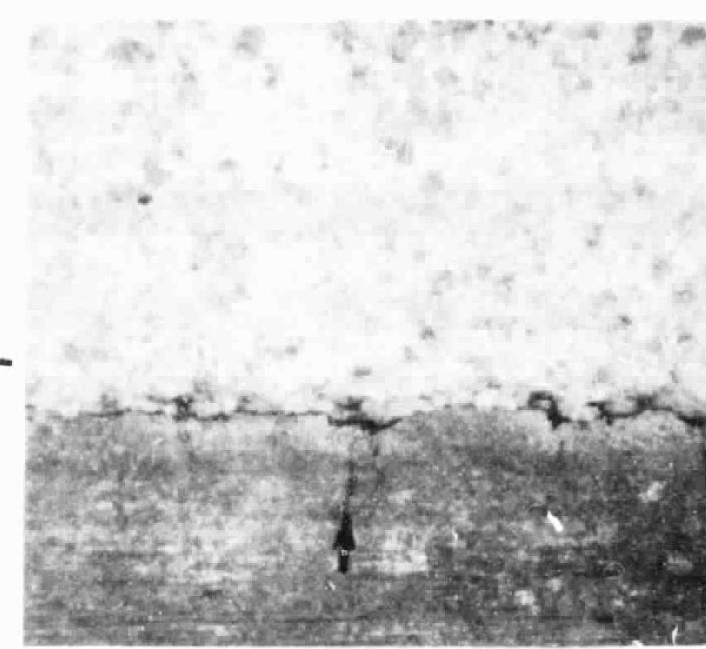

(b) Right-end bond line and verticle crack.

Figure 14. - Macrographs of ceramic shroud section. Magnification, 32.

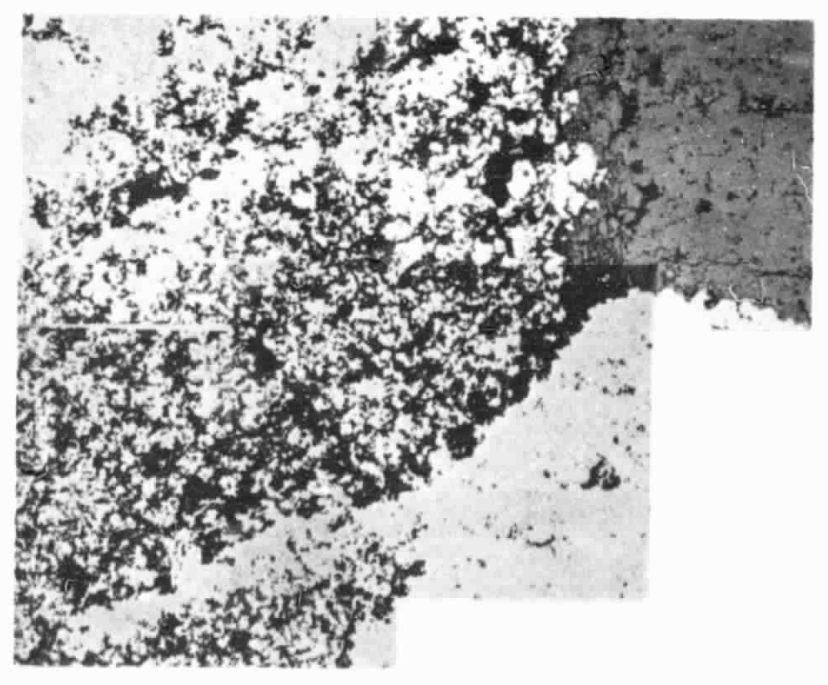

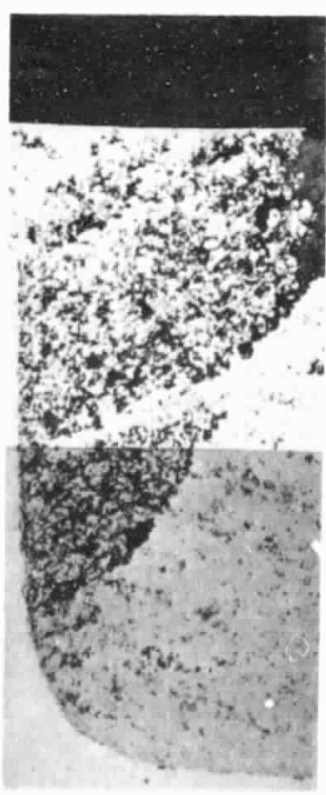

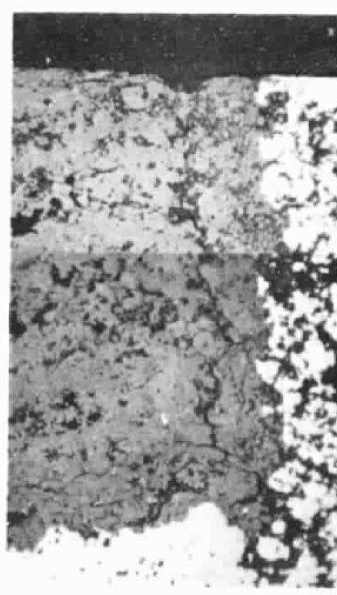

(b) Trailing edge.

Figure 15. - Low density in bond coat adjacent to leading and trailing-edge frames. 


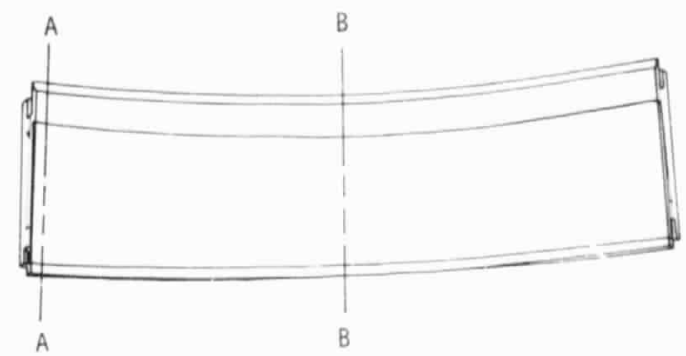

Figure 16. - Metallographic sectioning locations.
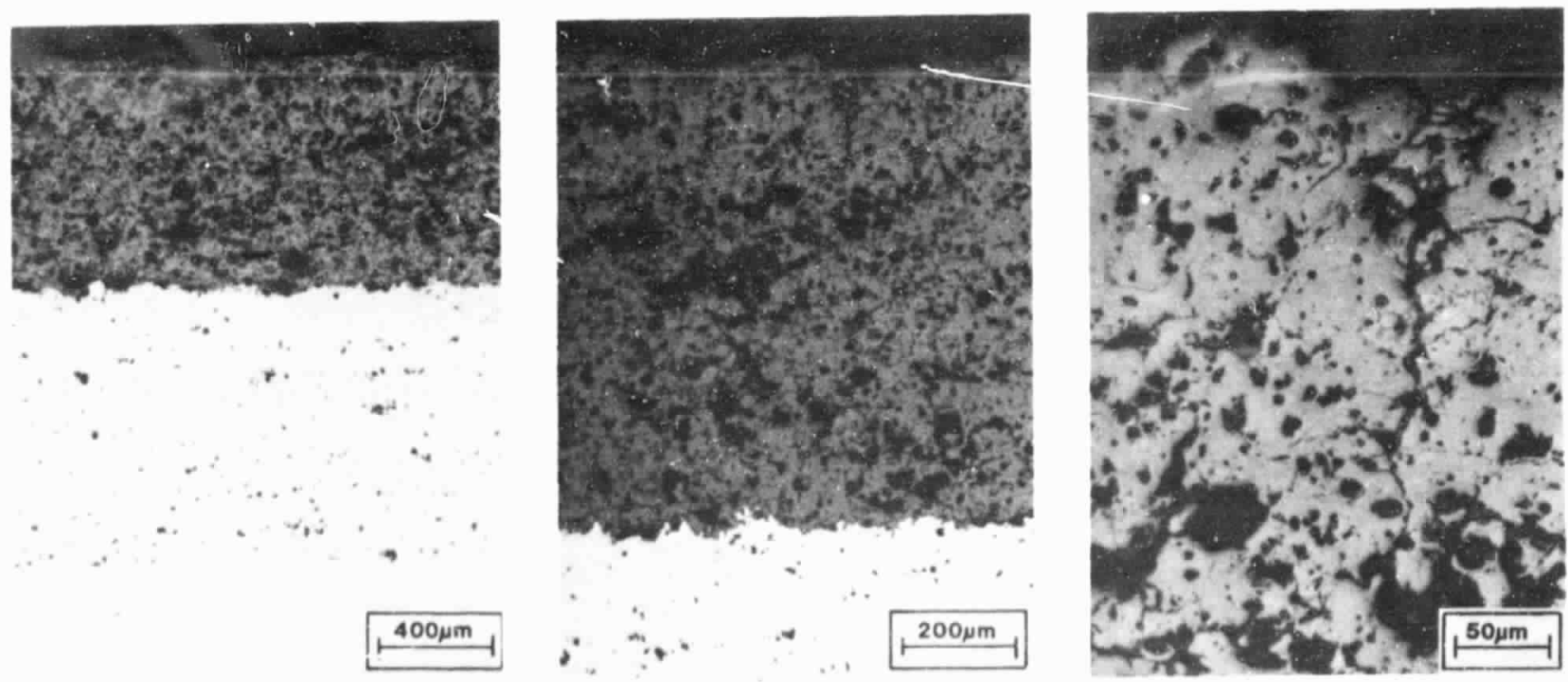

(a) Pretest microstructure; cross section B-B.

Figure 17. - Plasma-sprayed shroud seal. (See fig. 16 for cross-section positions.) 

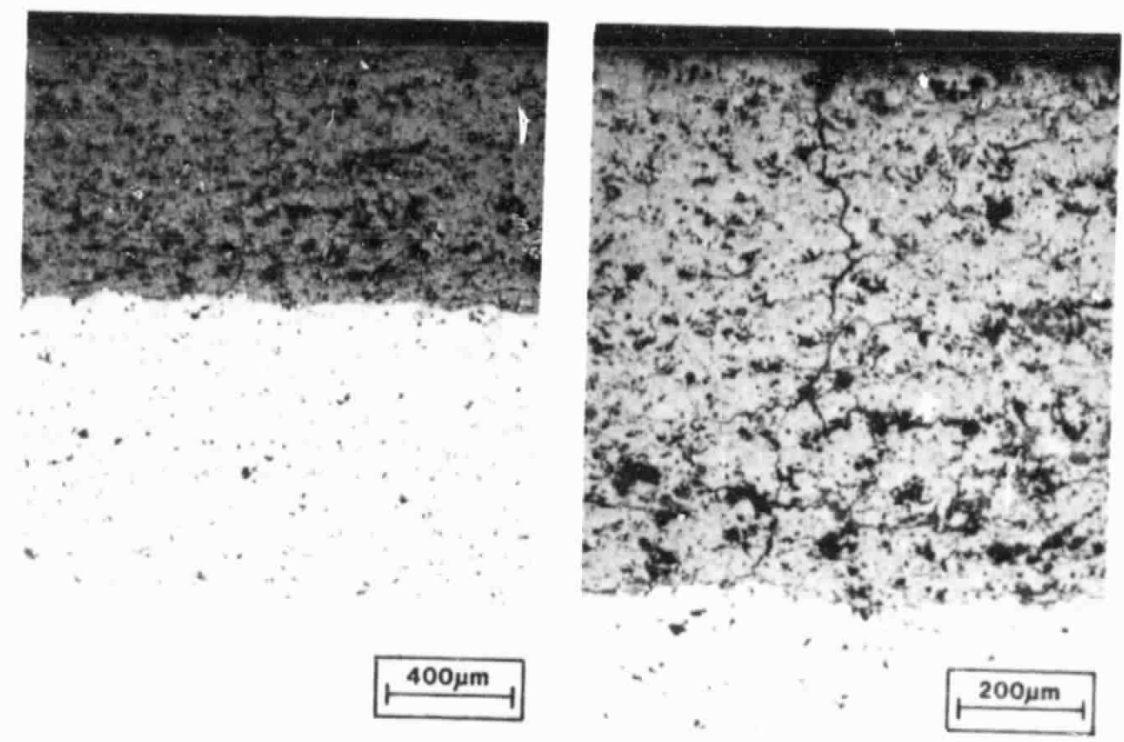

(b) Post-test microstructure; cross section A-A.

Figure 17. - Continued.

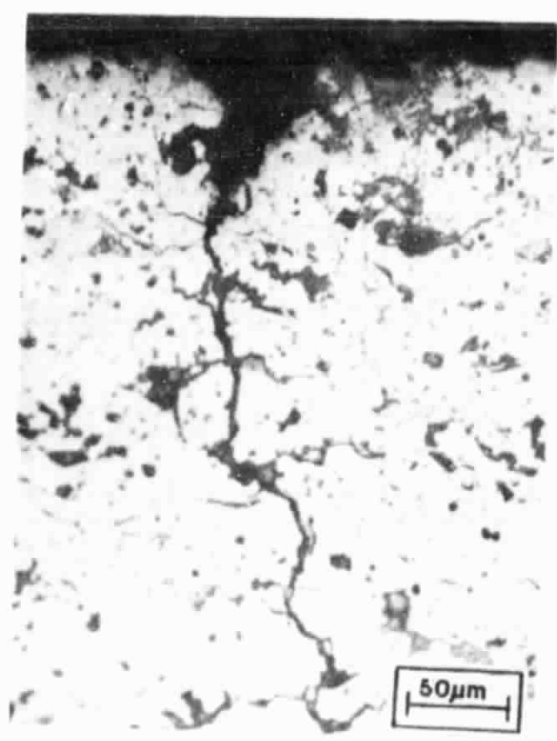

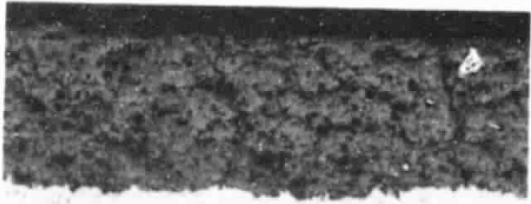

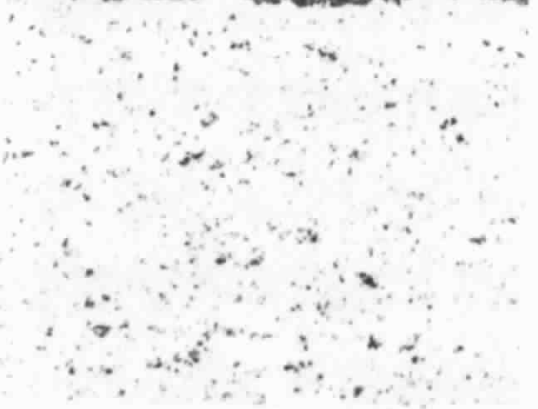

$400 \mu \mathrm{m}$
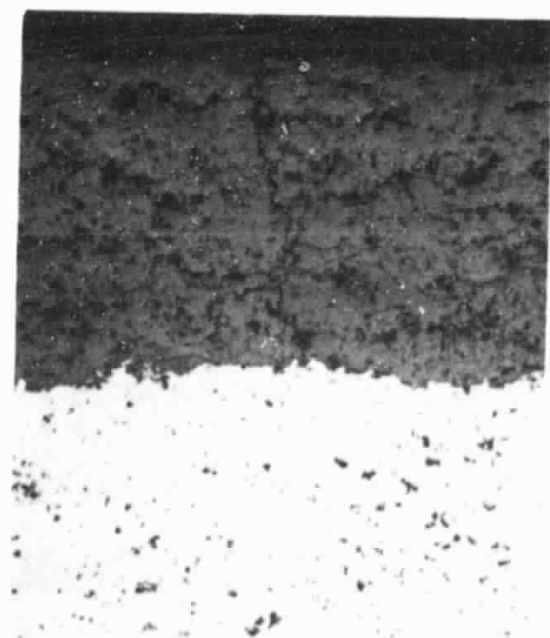

$\frac{4}{2}=2+\cdots$

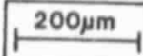

(c) Post-test microstructure; cross section B-B.

Figure 17. - Concluded.

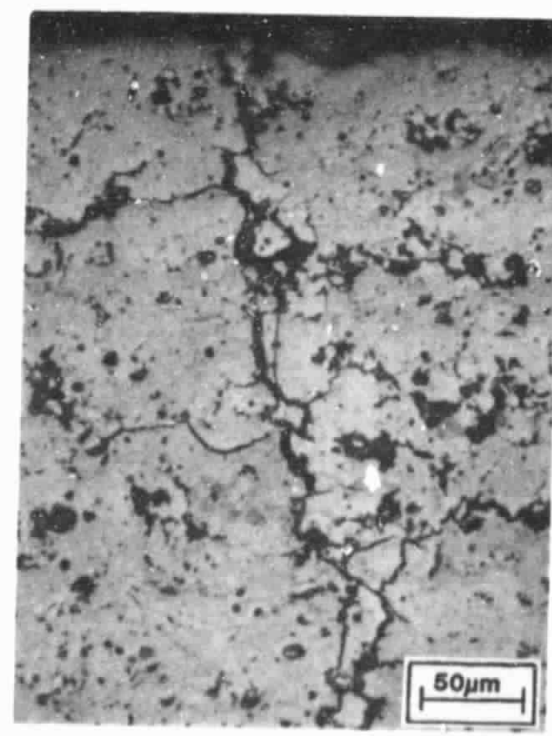

